This item was submitted to Loughborough's Research Repository by the author.

Items in Figshare are protected by copyright, with all rights reserved, unless otherwise indicated.

\title{
Conversation Analysis at the fair
}

PLEASE CITE THE PUBLISHED VERSION

https://doi.org/10.1177/1461445618754580

PUBLISHER

SAGE $\odot$ The Authors

VERSION

AM (Accepted Manuscript)

PUBLISHER STATEMENT

This work is made available according to the conditions of the Creative Commons Attribution-NonCommercialNoDerivatives 4.0 International (CC BY-NC-ND 4.0) licence. Full details of this licence are available at: https://creativecommons.org/licenses/by-nc-nd/4.0/

\section{LICENCE}

CC BY-NC-ND 4.0

\section{REPOSITORY RECORD}

Antaki, Charles. 2019. "Conversation Analysis at the Fair”. figshare. https://hdl.handle.net/2134/33647. 
Antaki, C. (2018). Conversation Analysis at the fair. Discourse Studies, 20(3), 425-430.

\section{$\underline{C A}$ at the fair}

Charles Antaki

Department of Social Sciences

Loughborough University

Loughborough

LE11 3TU

\section{Abstract}

The authors of the "Conversational Rollercoaster" article (Albert, Albury, Alexander, Harris, Hofstetter, Holmes and Stokoe (date 20xx/this issue) give a vivid and engaging account of a difficult but worthwhile exercise: bringing live Conversation Analysis to the public in a Science Fair. Part of their motivation is a claim that CA is uniquely qualified for such exhibition: as a mode of enquiry it has what they call a "public ethos". I examine that part of their case, and suggest that it might not be as waterproof as it appears. But such qualms ought not detract from the positive benefits of sharing CA's attractions with the public. The manifest success of the event, and its grounding in solid CA practice, is enough reason to hope that others will be inspired to follow in these pioneers' footsteps.

Psychologists sometimes tell each other the story of how, in 1884, Francis Galton not only got thousands of people to do his battery of psychophysical tests, but to pay him threepence each for the privilege. If only, psychologists will say, we could set up a booth in an exhibition hall, as Galton did, and get the public to pay to do our experiments on them! Well, perhaps. We can skate over Galton's unpalatable eugenic motivation for his datamining ${ }^{1}$, and celebrate instead the happier idea of getting the social sciences out there in the world to be seen, appreciated and contributed to by ordinary people.

That was the admirable motivation behind the "Rollercoaster" project described in Albert, Albury, Alexander, Harris, Hofstetter, Holmes and Stokoe's article (date 20xx/this issue). They set up a stall in an exhibition hall, and offered passers-by the chance for their interactions to be studied - in their case, videoed and subjected to close analysis - and they even got to the public try some analysis themselves. It was a brave enterprise- and it seems to have been a resounding success ${ }^{2}$. What can we learn from it?

\section{The rationale}

\footnotetext{
${ }^{1}$ He wanted to show that parents passed on the intelligence to their children - support, in his eyes, for selective breeding; but went away disappointed at finding no correlation (Colman, 1987/1993 p 18). ${ }^{2}$ Disclosure: I was on the fringes of the early preparation for the event, and took a minor part in the proceedings on the first day.
} 
Albert et al - I'll refer to them from now as 'the authors' so as to spread the credit fairly might have mounted the event just as a celebration of interactional studies in general, and Conversation Analysis in particular. As a celebration they'd have been following not so much in Galton's footsteps (who wanted the data for his own dark purposes) but those of the more humane and forbearing figure of Frederic Bartlett, who, in May 1913 "for several hours, sat in a darkened room exposing geometrical forms, pictures and a variety of optical illusions to the brief examination of a long string of visitors" (1932/1977 p. v). Bartlett was proudly showing off Cambridge's new Laboratory of Experimental Psychology, and the authors here want to show off CA, with the same hope: that it stimulate the public, and promote the idea that science could be accessible as well as profound.

This new event would set up a stall at the huge 2016 New Scientist exhibition in London, and demonstrate CA just as neighbouring stalls would demonstrate such wonders as virtual-reality kits, or computerised clothing. The experience would be appreciated and enjoyed, with the science as a moral warrant for all the fun. But - because this was all happening in a Science Exhibition - the person at the stall would be conscious that their vivid, particular and personal experience was a scientific one, and would go away more informed about, and better disposed to, that specific kind of science that they'd had their hands on, and science in general. If CA could be plugged into that scheme, it would fulfil the authors' ambition to find "new ways to engage partners in dialogue both within and beyond academia to promote greater awareness of rigorous empirical research into human interaction" (Albert et al, date 20xx/this issue, p xxx).

Probably most students of CA would support that sort of campaign, without further cause. But the authors have a still more ambitious story to tell. For them, there is something special about CA that gives its public demonstration a particular weight. CA, according to this view, is undervalued: not only is it about the public world of talk (or interaction more generally) but, as a mode of enquiry it is a "public science", and has what they call a "public ethos", and that makes its exposure to the world all the more urgent. Moreover, they hold that getting members of the public to comment on what they see on video can reveal things which might be "viable for use in future research, and that they therefore constitute practical, endogenous evidence of 'impact'". What do they mean by these claims, and are they true? And need they be, to get CA out there in such things as a science exhibition?

\section{Conversation Analysis as a "public science"}

The authors set out three kinds of evidence for their claim that CA is a "public science": talk is inherently public; CA practice is to show and share the raw data on which it works; and CA can say something about troublesome public worries like sexuality, class and gender. Readers of this journal will be happy enough with the first proposition, that talk is public; but there is reason to be cautious about the nature of the 'public' in the latter two claims.

In the case of data, certainly it is part of CA's manifesto that the analysts make their data available, to show their working. But there are familiar grounds to worry about quite what transformation data suffers when CA researchers make it public, in the transcriptions that appear in publications and even in raw form as viewed or heard in data sessions. The authors soft-pedal the problems, but, as they and other students of CA know, the concerns 
start right back at the beginning. Gail Jefferson herself issued caveats about her own transcription, taken up and expanded by Ochs' (1979) first statement of the transcriptionas-theory problem. Matters got more complicated with the rise of affordable video cameras (Goodwin, 1993, was an early guide to the complexities of filming for interactional research), prefiguring the current debate over what gets presented as data (Ayaß, 2015) or indeed recorded as 'data' in the first place, in terms of the selection of date, time, place, camera position, camera angle, the duration of the shot, its composition and so on (see, for discussions Heath et al, 2010, and Broth et al, 2014).

So although it is certainly part of CA doctrine that data is made public, the claim has to be hedged about with qualifications about quite what one should make of any given example, since by necessity even the careful reader of articles will not be aware of all the contingencies that landed this particular snippet in front of them. Seasoned CA readers know that they're not usually told all that much about the ethnographic circumstances of the data-collection, let alone, in the case of on-the-hoof video, the recorder's moment-bymoment decisions about framing, duration and so on. So yes, CA's data is 'public' in the sense that (some of) it is shared, but only after a complicated and not always conscious series of choices in how it got recorded in the first place, and another equally veiled and perhaps ad-hoc series of choices in how it's presented once it's clipped out of the analyst's audio- or video file. So that leg of the table is a bit shaky. I should quickly say that none of this invalidates the Rollercoaster authors' account of the analysis of what's in front of the reader. That lives or dies by virtue of the skill of the analyst in deploying now wellestablished CA apparatus. It's the Rollercoaster authors' 'public-ness' of CA data that perhaps oughtn't be relied on quite at face value, if one is thinking of a general principle. As it happens, their own practice at the science fair was much more transparent - the observer could see more or less exactly where the data came from (a round-table discussion right in front of them), and would be able to make a fair judgement about whether any snatch of it was a fair one. But the authors would be making something of a leap to imply that this was how CA dissemination usually worked.

As for CA's commitment to the public world, there is a definite queasiness among some commentators, outside CA, about its claims to say anything about what's really publicly important - see, to pick examples over time, CA's treatment at the hands of the critical discourse analysts Fairclough (1992) or Parker (2005). Students of CA and readers of this journal may be more familiar with the uncomfortable exchange in these pages between Schegloff $(1997,1998,1999)$ Wetherell $(1998)$, and Billig (1999) which laid bare one principal bone of contention - that, without context, no interaction is fully intelligible; and that context must (allegedly) include the not-necessarily-visible political, ideological and cultural forces that are sending down waves of influence from far overhead. The Rollercoaster authors are of course perfectly aware of the quarrel, but they put their money on the side that claims that, if something is operative, then it will show up on the ground, in the details of the interaction. So studies which show that people orient - in their recordable talk - to sociological categories like sexuality, class or race are evidence that CA is indeed about the public sphere. (They might also have mentioned the small but growing number of CA studies which use distributional statistics, in traditional social-science ways, to map conversational practices onto sociological categories, even if the participants in the scene never openly advert to those categories (for example, Stivers and Majid on doctors' 
questioning of children of various races, 2007). This isn't the place to arbitrate on such a large question, but I think it's probably fair to say that someone coming from outside CA would be unimpressed with its claims to simply letting the data speak sociologically and politically for itself.

So two of the legs of the authors' arguments might not be quite as sturdy as they would like, at least were they to be tested by someone who had heavy qualms about the idea of public (in the sense of un-mediated) 'data' and public (in the sense of fully accountable) 'context'. For those already in the CA camp, I imagine that such worries would be part of a general intellectual wrangle that they're long used to coping with, and won't be too much of a hindrance to the public-science project that the Rollercoaster so enthusiastically embodies.

\section{Impact}

Impact is the Rollercoaster project's strongest suit, whatever the reader's intellectual commitments. The authors' account gives a lively sense of the at times hectic, complex interplay of desk-based analysts, camera operators, peripatetic explainers, and talk-show round-table conversationalists at the heart of it. The video that the authors made of the event (<https://www.youtube.com/watch?v=HukdRTn|228\&t=187s $>$ ) captures the bustle. At the heart of it is, as the authors are at pains to point out, some real, real-time CA; they could have faked it by bringing along some more or less predictable already-known examples of the kind of thing that happens in conversation, but, as they say, that would badly diminish the authenticity of the spectacle. Theirs was a high-risk act, in which analysts worked quickly (but honourably) on the data that streamed in live from the camera, they spotted something that looked like a practice, and worked it up and handed it to the explainers, who fed it back out to the people who had seen in in real time. That's a lot of plates to keep spinning.

The pleasing thing is that it worked, certainly as a spectacle, and well enough for authors to report that some members of the passing public "got it" in the way that one sometimes sees university students, fresh to CA, get it on first exposure. And members of the public are a much tougher audience. To be sure, they were enjoying a performance that we never trouble to present to our students; those get the dry biscuit of a transcript and, if they're lucky, a carefully neutralised bit of rather dull video. So here is an engaging picture of clever people doing technical computer work on images taken from the scene in front of them, and making it their business to reach out and seduce them into understanding things in that scene that they'd not quite noticed before. In their article, the authors smartly recruit the voices of two young people who got caught up in that cycle, got enthused by what they saw, immersed themselves in it, and came up with their own analytical take on the data. That's the gold achievement that the authors were trying for: indigenous, but sophisticated, public analysis. Quite a coup.

"Impact" is now a cultural trope in the world of UK higher education (and no doubt elsewhere too, under that name or some other). Academics have to demonstrate that we make a difference. The big-ticket differences are in places where there is some measurable social good, usually indexed by money. But outreach of this kind counts as well, to administrators as well as to we ourselves, who want our science to get an airing and to be 
valued. Mounting an active, engaging show, drawing in many hundreds of people, is a terrific example of how to make an impact without compromising the central virtues of the science and scholarship that you're trying to promote.

\section{Conclusion}

Outside of the CA community, and perhaps among some inside it, not everyone will be wholly confident about the authors' 'public ethos' platform, or at least the reliability of its 'public data' and 'public commitment' planks. But the authors' enterprise - with so much more of an attractive motivation than Galton's, and promising more excitement than Bartlett's ${ }^{3}$ - will surely appeal anyway. There is a buzz in making language-in-interaction work as a science, in real time, in front of a large audience who are ready to appreciate it and even to muck in and have a go themselves. The authors' pioneering efforts ought to inspire many CA people to try something similar, though it's true that the set-up is complicated, and wants funding, planning, and co-ordination among technicians, analysts and people willing to put on an extroverted show. That doesn't come cheap in money or time. But the success of the Rollercoaster shows that it merits the investment, and should encourage other academics to try their own version of it, away from academia and out in the public world.

\section{$\underline{\text { References }}$}

Ayaß, R. (2015). Doing data: The status of transcripts in Conversation Analysis. Discourse Studies, 17(5), 505-528.

Bartlett, F (1932 / 1977) Remembering: a study in experimental and social psychology. Cambridge: Cambridge University Press

Billig, M. (1999). Whose terms? Whose ordinariness? Rhetoric and ideology in conversation analysis. Discourse \& Society, 10(4), 543-558.

Broth, M., Laurier, E., \& Mondada, L. (Eds.). (2014). Studies of video practices: Video at work. Routledge.

Colman, A. M. (1987/1993). Facts, fallacies and frauds in psychology. London: Routledge.

Kendrick, K. H. (2017). Using Conversation Analysis in the Lab. Research on Language and Social Interaction, 50(1), 1-11.

Fairclough, N (1992) Discourse and Social Change. Cambridge: Polity Press, 1992

Goodwin, C. (1993). Recording Interaction in Natural Settings. Pragmatics 3(2): 181-209.

\footnotetext{
${ }^{3}$ Though, in time, CA demonstrations might well include laboratory apparatus, if Kendrick's (2017) recommendation for greater use of experimentation bears fruit.
} 
Heath, C., Hindmarsh, J., \& Luff, P. (2010). Video in qualitative research. London: Sage Publications.

Ochs, E. (1979). Transcription as theory. Developmental pragmatics, 10(1), 43-72.

Parker, I. (2005). Qualitative psychology: Introducing Radical Research. Maidenhead: Open University / McGraw-Hill Education (UK).

Schegloff, E. A. (1997). Whose text? Whose context?. Discourse \& society, 8(2), 165-187.

Schegloff, E. A. (1998). Reply to Wetherell. Discourse \& Society, 9(3), 413-416.

Schegloff, E. A. (1999). Schegloff's 'texts' as Billig's 'data': A critical reply. Discourse \& Society, 10(4), 558-572.

Stivers, T., \& Majid, A. (2007). Questioning children: interactional evidence of implicit bias in medical interviews. Social Psychology Quarterly, 70(4), 424-441.

Wetherell, M. (1998). Positioning and interpretative repertoires: Conversation analysis and post-structuralism in dialogue. Discourse \& society, 9(3), 387-412.

Bio

Charles Antaki is Professor of Language and Social Psychology at Loughborough University, in the Department of Social Sciences. His research interests are in Conversation Analysis, and among his publications is the edited collection Applied Conversation Analysis: Intervention and Change in Institutional Talk (Palgrave Macmillan, 2011). He is editor of the journal Research on Language and Social Interaction. 